Article

\title{
Physico-Chemical Properties of Sugar Beet Pectin-Sodium Caseinate Conjugates via Different Interaction Mechanisms
}

\author{
Juyang Zhang * and Bettina Wolf ${ }^{+}(\mathbb{D}$ \\ Division of Food Sciences, School of Biosciences, University of Nottingham, Sutton Bonington Campus, \\ Loughborough LE12 5RD, UK; B.Wolf@bham.ac.uk \\ * Correspondence: juyangzhang@outlook.com \\ + Current Address: School of Chemical Engineering, University of Birmingham, Birmingham B15 2TT, UK.
}

Received: 14 May 2019; Accepted: 30 May 2019; Published: 3 June 2019

\begin{abstract}
Polysaccharides and proteins are frequently conjugated through electrostatic attraction, enzymatic cross-linking, and heat treatment (Maillard reaction) to obtain food structuring ingredients, mostly for their application as emulsifiers. The conjugate partners and their interaction type affect performance at acidic or neutral $\mathrm{pH}$ and during thermal processing, thus requiring careful selection. Here, the aggregate properties (particle size, conjugate charge, shear viscosity) of three types of sugar beet pectin (SBP)-sodium caseinate (SC) 1:1 conjugates, at acidic and neutral $\mathrm{pH}(4.5 ; 7)$, as well as their thermal processing stability $\left(80^{\circ} \mathrm{C}\right)$, were investigated. The enzymatically cross-linked SBP:SC was more acid tolerant than the electrostatically interacting conjugates. Maillard cross-linked conjugates aggregated at $\mathrm{pH} 4.5$, suggesting poor emulsifier performance in acidic conditions. At $\mathrm{pH} 7$, the three conjugate types showed similar aggregate properties. The results are discussed in terms of structural re-arrangement.
\end{abstract}

Keywords: sodium caseinate; sugar beet pectin; electrostatic interaction; enzymatic cross-linking; Maillard reaction; polysaccharide-protein complex; acidic $\mathrm{pH}$ and thermal processing

\section{Introduction}

The quality of a food product is characterised by its texture, structure, and stability as imparted by the intrinsic functional properties of the ingredients and their interactions during the manufacturing process. Polysaccharides and proteins both improve the microstructure and stability of multiphase food systems because of their physicochemical functional properties at interfaces [1]. The structural functionality of a polysaccharide and protein concomitantly present in a formulation may be the result of the interaction with each other, prompting an improvement in individual biopolymers' functional properties [2]. Indeed, polysaccharide-protein complexes are widely applied in the field of encapsulation, protection and delivery of functional food ingredients, such as bioactive lipids, minerals, enzymes, peptides and so forth [3,4]. Moreover, the application of polysaccharide-protein complexes as fat replacer has been reported. Examples include, complexes prepared from milk protein and xanthan gum [5], milk protein and carrageenan [6], soy protein and xanthan gum [7], as well as casein and pectin [8]. Milk proteins, such as casein, are aggregated with lowering $\mathrm{pH}$ conditions. To improve the solubility of casein under acidic conditions, some polysaccharides have been introduced, for instance, pectin $[9,10]$.

Casein presence is essential for the structural integrity of dairy products, such as cream, cheese and butter, and also provides essential amino acids. In addition, the use of casein micelles has been suggested as an ideal encapsulation vehicle for nutraceuticals, such as fat-soluble vitamins $[11,12]$. There are four 
types of casein: $\alpha_{\mathrm{s} 1}$-casein, $\alpha_{\mathrm{s} 2}$-casein, $\beta$-casein, and $\mathrm{k}$-casein, all of which possess different structures and functionality. All four caseins in milk aggregate into casein micelles spontaneously as a result of the interaction with calcium phosphate [11,13-15]. Both $\alpha$ s1-casein and $\beta$-casein are major caseins, which have the tendency to self-associate because of their amphiphilic nature. However, $\beta$-casein forms spherical micelles, whereas $\alpha_{\mathrm{s} 1}$-casein is characterised by chain-like aggregates, due to the presence of a stronger net negative charge, as both proteins are at neutral $\mathrm{pH}$ [13]. In contrast, $\mathrm{k}$-casein is a glycoprotein, which can sterically stabilise casein micelles formed by $\alpha_{\mathrm{s} 1}$-casein, $\alpha_{\mathrm{s} 2}$-casein and $\beta$-casein $[13,15]$. Pectin is a heteropolysaccharide, which is extensively used in food production, due to its gelling and stabilising properties [16]. The structure of pectin consists of a backbone of 1-4-linked D-galacturonic acid (GalA) units interrupted by some rhamnogalacturonan segments, which combine galacturonic acid residues and a-L-rhamnopyranose. Side chains are glycosidically linked to O-4 and/or O-3 of L-rhamnopyranose, and O-2 or O-3 of some of the galacturonosyl residues. In addition, there are sugar constituents attached as side chains, such as D-galactose and L-arabinose. These sugars are present in galactan, arabinogalactan and arabinan. In addition, ferulic acid, which has a phenolic acid structure, ester-links to either, arabinose or galactose [16-19]. Generally, pectin is extracted from plant cell walls, such as citrus peels, apple pomace and sugar beet pulp. Sugar beet pectin can be obtained from sugar beet pulp during the extraction of sugar [17].

The study, presented here, was dedicated to evaluating the physicochemical properties of polysaccharide-protein conjugates, that were prepared from sugar beet pectin (SBP) and sodium caseinate (SC), for the future application of these conjugates as emulsifiers. In principle, there are three methods applicable for the preparation of food-grade polysaccharide-protein conjugates: Electrostatic interaction, enzymatic methods and Maillard reaction. The most popular method for the formation of polysaccharide-protein conjugates is electrostatic interaction between opposing charges on the two biopolymers [20]. Polysaccharides are characterised by anionic, cationic or non-ionic charges, which correlate with the nature of functional groups, but are also influenced by $\mathrm{pH}$ conditions, based on the $\mathrm{pKa}$ value of the ionisable side groups [21]. SBP possesses only carboxylates $\left(-\mathrm{CO}^{2-}\right.$, pKa about 2.5 to 4.5) as ionisable group and is net-negatively charge [22]. SC is a protein that possesses both positive and negative charges, because of protonated amino side groups $\left(-\mathrm{NH}^{3+}\right)$ at a $\mathrm{pH}$ of below 10 and deprotonated carboxylate side groups $\left(-\mathrm{CO}^{2-}\right)$, at a $\mathrm{pH}$ higher than two, respectively. The isoelectric point ( $\mathrm{pI}$ ), the $\mathrm{pH}$ at which the net-charge is zero, is $\sim 4.6$ [21].

Unlike the electrostatic interaction method, an enzymatic method is based on chemical cross-linking. Laccase is a multi-copper, polyphenol oxidase obtained from bacteria, fungi and plants [23,24]. It generates free radicals by oxidising various compounds, such as amines, thiols and iodine [25], typically phenoxy radicals with a loss of single electrons to form radicals, including quinones and/or phenoxy radicals $[24,26]$. In addition, laccase is capable of catalysing ferulic acid, which is a phenol structure esterified to the arabinose side-chain at the backbone of the rhamongalacturonan I side chains in SBP. In the presence of oxygen these side chains are enzymatically oxidised into FA dihydrodimers (diFAs) [27]. It has previously been reported that the emulsification properties of SBP improved following inter-molecular cross-linking via laccase catalysis [26]. Furthermore, SBP has been shown to improve the stabilisation of emulsion systems prepared by using whey protein [27-29], fish gelatine $[30,31]$ and $\beta$-lactoglobulin $[32,33]$ via cross-linking of SBP through the addition of laccase. In addition, laccase has the ability to oxidise tyrosine and tyrosine-containing peptides, as ferulic acid can become covalently cross-linked into the polymer structure through an ether bond [23]. Laccase can also oxidise amino acids, such as cysteine and phenol-based tryptophan [25,29,34]. It has also been reported that laccase can catalyse SC and can form inter-molecular bonds between the caseinate molecules [35]. Therefore, it can be inferred that three structures may be involved in SBP-SC conjugates via laccase catalysis, namely SBP-SC, SBP-SBP and SC-SC conjugates.

Finally, the Maillard reaction is a non-enzymatic browning reaction that occurs during heating, roasting, baking and frying in the presence of both carbohydrates and proteins in food products [36]. The Maillard reaction has favourable effects, such as colour and flavour formation during 
roasting, baking or frying, whereas it is unfavourable in processes, such as drying, pasteurisation and sterilisation [37]. The Maillard reaction is a chemical reaction, cross-linking aldehydes and amines, through a well-established oxidation-reduction pathway [21]. For common proteins and polysaccharides, the Maillard reaction occurs between amino compounds and reducing sugars as reactants [37]. The major variables, that impact upon the Maillard reaction, are not only temperature, time and relative humidity, but also the nature and proportion of each polymer [38]. Generally, the Maillard reaction involves three stages, and the first stage may be enough for improving the emulsification properties of conjugates [39]. This stage naturally occurs between the carbonyl group of polysaccharides and amino acids of proteins, in order to isomerise the Amadori product, which is the product of the condensation process, via the formation of a Schiff base with the release of water and the Amadori rearrangement $[20,36,39]$.

All three types of conjugates were created from SBP and SC and their aggregation properties

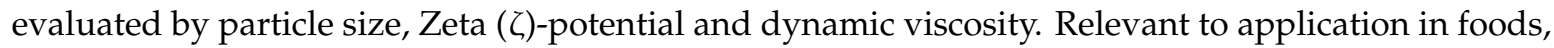
the effect of environmental stress factors, including $\mathrm{pH}$ conditions, $\mathrm{pH} 4.5$ and $\mathrm{pH} 7$, and thermal treatment at $80{ }^{\circ} \mathrm{C}$ for $10 \mathrm{~min}$, on the aggregation properties was also assessed. Finally, SBP-SC interaction models are proposed.

\section{Materials and Methods}

\subsection{Materials}

The main materials used to prepare the polysaccharide-protein conjugate emulsifiers, and appropriate reference samples, were sugar beet pectin (Herbstreith \& Fox KG, Neuenbürg, Germany) sodium caseinate, citric acid monohydrate and sodium citrate dihydrate for the preparation of citrate buffers ( $\mathrm{pH} 4$ and $\mathrm{pH}$ 5), hydrochloric acid and sodium hydroxide to adjust the $\mathrm{pH}$ with $1 \mathrm{M}$ solutions, sodium azide as antimicrobial (purchased from Fisher Scientific, Loughborough, UK), ferulic acid, potassium bromide, syringe filters $(0.45 \mu \mathrm{m}, \varnothing 15 \mathrm{~mm}$, Whatman GE Healthcare) and laccase enzyme (purchased from Sigma-Aldrich, Gillingham, UK). The laccase activity was reported by the supplier as 0.87 units per mg (AU) of the enzyme. Deionized water (electrical conductivity $<2 \mu \mathrm{S} \mathrm{cm}{ }^{-1}$ ) produced on-site was used throughout.

\subsection{Dispersion Preperation}

A $0.1 \mathrm{M}$ Citrate buffer ( $\mathrm{pH}$ 5) was prepared by mixing $20.5 \mathrm{~mL}$ of $0.1 \mathrm{M}$ citric acid and $29.5 \mathrm{~mL}$ of $0.1 \mathrm{M}$ sodium citrate with $50 \mathrm{~mL}$ of water on a magnetic stirrer at $500 \mathrm{rpm}$ and $25^{\circ} \mathrm{C}$ for $30 \mathrm{~min}$. The solution was then diluted with water to obtain $50 \mathrm{mM}$ citrate buffer at $\mathrm{pH} 5$ to use as solvent. Dispersions of different ferulic acid concentrations $(0.1-1.5 \mathrm{mg} / 100 \mathrm{~g})$ were prepared in $50 \mathrm{mM}$ citrate buffer ( $\mathrm{pH}$ ) by dissolving ferulic acid powder in the appropriate amount of water on a magnetic stirrer at $500 \mathrm{rpm}$ and $25^{\circ} \mathrm{C}$ for $2 \mathrm{~h}$ to ensure full dissociation.

An amount of 0.1 or $1 w / w \%$ SBP dispersion was prepared by dissolving $1 \mathrm{~g}$ of SBP powder in the appropriate amount of water and citrate buffer $(50 \mathrm{mM})$, followed by mixing on a magnetic stirrer at $500 \mathrm{rpm}$ and $25^{\circ} \mathrm{C}$ overnight. SC dispersion, at a total polymer concentration of $1 w / w \%$, at $\mathrm{pH} 7$, was prepared by dissolving $1 \mathrm{~g}$ of SC powder in the appropriate amount of water on a magnetic stirrer at $500 \mathrm{rpm}$ and $25^{\circ} \mathrm{C}$ for one hour to ensure full hydration. A 1:1 SBP:SC dispersion was prepared by mixing $1 w / w \%$ SC and SBP dispersions, with the appropriate amount of deionized water, containing $0.02 w / w \%$ sodium azide.

Different laccase/sugar beet pectin ratios were prepared at $\mathrm{pH}$ 5, namely: $1.15 \mathrm{mg} / 4 \mathrm{mg}$ (1 AU); $5.75 \mathrm{mg} / 4 \mathrm{mg}$ (5AU); $11.5 \mathrm{mg} / 4 \mathrm{mg}$ (10AU); and $23 \mathrm{mg} / 4 \mathrm{mg}$ (20 AU). Thus, $2.3 \mathrm{w} / \mathrm{w} \%$ enzyme was prepared by dispersing $2.3 \mathrm{~g}$ of laccase in the appropriate amount of water and $50 \mathrm{mM}$ citrate buffer, followed by $1 \mathrm{~h}$ of stirring for complete hydration. Then, $50 \mathrm{~g}$ laccase/SBP mixture dispersion was prepared by mixing $2.3 w / w \%$ laccase and $0.1 w / w \%$ SBP dispersion with the appropriate amount of citrate buffer $(50 \mathrm{mM})$ at $25^{\circ} \mathrm{C}$. 


\subsection{Analysis of Ferulic Acid Concentration and Selection of Experimental Conditions for Laccase-Catalysed Cross-Linking of Sugar Beet Pectin and Sodium Caseinate}

The proportion of ferulic acid in the SBP, obtained for this study, needed to be quantified to select the appropriate experimental conditions for the laccase-catalysed cross-linking of SBP and SC. A previously published method, based on UV visible spectroscopy [30], was applied. The maximum absorbance for SBP is at $325 \mathrm{~nm}$ wavelength, which is attributed to the presence of ferulic acid groups in this material [30]. The absorbance of the different concentrations of ferulic acid dispersions was determined at $325 \mathrm{~nm}$, by using a UV-visible light spectrophotometer (HP 8453 Agilent, Agilent Technologies, Waldbronn, Germany) at $25^{\circ} \mathrm{C}$. A total of $50 \mathrm{mM}$ citrate buffer (pH 5) was used as a blank. Based on the standard curve reported in Figure S1a (Supplementary Materials) and absorbance of a $0.1 \%$ $w / w$ SBP dispersion, it was established that the SBP contained 1.33\% ferulic acid. Then, a standard curve of the calibration dispersions was plotted as a function of the ferulic acid concentration from $0.1-1.5 \mathrm{mg} / 100 \mathrm{~g}$. To calibrate the absorbance signal.

Having established the proportion of ferulic acid in the SBP, it was assessed whether laccase would cross-link the SBP molecules following previously published protocol for laccase activity assessment $[30,33]$. Laccase/SBP mixture dispersions were gently shaken and then immediately sampled into the spectrophotometer and absorbance at $325 \mathrm{~nm}$ followed for $60 \mathrm{~min} .1,5$ and $10 \mathrm{AU}$ laccase activity were tested and since the absorbance data overlapped, see Figure S1b (Supplementary Materials), the intermediate of 5AU was chosen to carry forward.

\subsection{Preparation of Conjugate Dispersions}

Electrostatically, enzymatic and through Maillard cross-linked SBP-SC conjugate dispersions were prepared at a 1:1 by weight mixing ratio as described in the following.

\subsubsection{Laccase-Catalysed SBP Dispersions}

SBP dispersions were prepared as reference samples. A $0.4 w / w \%$ laccase-catalysed SBP dispersion was prepared by dissolving $1 w / w \%$ SBP dispersion in the appropriate amount of water, containing $0.02 \mathrm{w} / \mathrm{w} \%$ sodium azide and $10 \mathrm{~g} 5 \mathrm{AU}$ laccase dispersion on a magnetic stirrer at $500 \mathrm{rpm}$ and $25^{\circ} \mathrm{C}$ for $2 \mathrm{~h}$ to ensure complete catalysis. The completion of the enzymatic catalysis was determined by visual observation of the colour of the SBP dispersion, changing from turbid to clear brown. The dispersion was stored at $25^{\circ} \mathrm{C}$ until further use.

\subsubsection{Electrostatically-Stabilised SBP-SC Conjugate Dispersions}

To cross-link SBP and SC, the $\mathrm{pH}$ of the 1:1 SBP:SC dispersion with a total polymer content of $0.4 w / w \%$ was adjusted to 4.5 by the addition of either $1 \mathrm{M} \mathrm{HCl}$ or $1 \mathrm{M} \mathrm{NaOH}$, as appropriate. This was stirred at $500 \mathrm{rpm}$ and $25{ }^{\circ} \mathrm{C}$ for at least $6 \mathrm{~h}$ on a magnetic stirrer to ensure complete formation of SBP-SC conjugates. Observation of the completion of the conjugate formation process was possible visually as the SC dispersion was clear, whereas the SBP dispersion was turbid brown; upon conjugate formation the appearance changed from turbid brown to turbid white. The conjugate dispersion was labelled SBP:SC P (P to denote physical cross-linking by electrostatic interaction).

\subsubsection{Laccase-Catalysed SBP-SC Conjugates Dispersions}

A 1:1 SBP:SC dispersion with a total polymer content of $0.4 w / w \%$ was prepared by mixing the appropriate amounts of stock dispersions with deionized water containing 5 AU laccase enzyme. After that, the SBP-SC mixture was placed in a magnetic stirrer at $500 \mathrm{rpm}$ and $25^{\circ} \mathrm{C}$ for $2 \mathrm{~h}$ to ensure complete enzymatic reaction. The initially turbid white and finally turbid light brown appearing dispersion was labelled SBP:SC E (E to denote enzymatic cross-linking by laccase catalysis). 


\subsubsection{SBP-SC Maillard Conjugates Dispersions}

For the preparation of the SBP-SC Maillard conjugates a previously published protocol was followed [36]. SBP and SC were dissolved in deionized water (solid/liquid ratio 1:25) at a ratio of 1:1 while stirring at $700 \mathrm{rpm}$ and $25^{\circ} \mathrm{C}$ for $2 \mathrm{~h}$ on a magnetic stirrer. After that, the mixture was stored in a freezer at $-80^{\circ} \mathrm{C}$ for at least $24 \mathrm{~h}$ and followed by dehydration in a freeze-drier (Super Modulyo, Edwards, Burgess Hill, UK) at $-40^{\circ} \mathrm{C}$ and pressure between $7 \times 10^{-2}$ bar and $2 \times 10^{-2}$ bar. The dried solids were placed in a desiccator containing a saturated $\mathrm{KBr}$ dispersion and incubated for $48 \mathrm{~h}$ in a cabinet (Sanyo/Gallenkamp cabinet, model CF4) at $60{ }^{\circ} \mathrm{C}$, with a relative humidity of $79 \%$. The conjugates were stored in disposable polypropylene containers at $2{ }^{\circ} \mathrm{C}$ until further use.

Conjugate dispersions were prepared by dissolving $0.4 \mathrm{~g}$ of freeze-dried solids in an appropriate amount of deionized water, containing $0.02 w / w \%$ sodium azide and $10 \mathrm{~g}$ citrate buffer $(50 \mathrm{mM}$, $\mathrm{pH}$ 5), and then stirred at $500 \mathrm{rpm}$ and $25^{\circ} \mathrm{C}$ for $1 \mathrm{~h}$ on a magnetic stirrer to ensure full hydration, which was confirmed by the absence of visible solids. The buffer was used to ensure the same ionic strength conditions were present as for the conjugates prepared by electrostatic cross-linking and laccase catalysis. The $0.4 w / w \%$ SBP-SC conjugate via Maillard reaction dispersion was labelled as SBP:SC M dispersion ( $M$ to denote Maillard reaction).

\subsection{Analytical Methods}

\subsubsection{Conjugate Size}

The size of the different conjugates was quantified as the z-average as determined with a Zetasizer (Zetasizer Nano ZS (Malvern Panalytical, Malvern, UK)). Prior to analysis, conjugate samples were diluted with deionised water to a total polymer concentration of $0.01 w / w \%$, which gave an optimal sample concentration for measurement, as indicated by the instrument's software, and then filtered, using syringe filters to remove larger particles, such as dust and other contaminants. $3 \mathrm{~mL}$ of sample was then enclosed in a single-use disposable sizing cuvette (DTS0012, Sarstedt, Nümbrecht, Germany) and placed into the equipment at $20{ }^{\circ} \mathrm{C}$. The refractive index and absorption were set to be 1.450 , and 0.001 , respectively.

\subsubsection{Zeta-Potential Measurement}

To determine the $\zeta$-potential of the SBP-SC conjugates, a particle electrophoresis instrument (Delsa Nano C, Meritics, High Wycombe, UK) was used at $20^{\circ} \mathrm{C}$. Before the measurement, samples were diluted to $0.2 w / w \%$ with deionized water. The samples were measured 1 day after preparation.

\subsubsection{Shear Viscosity}

The shear viscosity of SBP-SC conjugate dispersions prepared at $\mathrm{pH} 4.5$ was analysed, using a rotational rheometer (Physica MCR 301, Anton Paar, Graz, Austria) fitted with a double gap cylinder geometry (DG26.7/T200/SS, Anton Paar, Graz, Austria). Before the measurement, the samples were shaken well in a vial to separate the aggregated conjugates. Then, each sample was loaded into the rheometer measurement cell and allowed to equilibrate at $20^{\circ} \mathrm{C}$ for $2 \mathrm{~min}$. Then, the steady shear behaviour of the samples was assessed as a function of shear rate from 1 to $100 \mathrm{~s}^{-1}$.

\subsection{Environmental Stress Tests}

The conjugate dispersions were submitted to a $\mathrm{pH}$ and a temperature stress test, followed by storing at $25^{\circ} \mathrm{C}$ for $24 \mathrm{~h}$ before analysis with the same analytical methods, as applied to the freshly prepared samples. 


\subsection{1. $\mathrm{pH}$ Adjustment}

The $\mathrm{pH}$ stress tests included, adjusting the $\mathrm{pH}$ of SBP-SC conjugates with $1 \mathrm{M} \mathrm{HCl}, 1 \mathrm{mM} \mathrm{HCl}$, and $1 \mathrm{M} \mathrm{NaOH}$, as required, to a value of 4.5 or 7 . These two $\mathrm{pH}$ values were selected because SBP-SC conjugates might split at both $\mathrm{pH} 4.5$ and $\mathrm{pH} 7$, as a result of residual charges of $\mathrm{SC}$, and opposite charges between two biopolymers, respectively.

\subsubsection{Thermal Stress}

A thermal stress test was designed as follows. SBP:SC 1:1 P, SBP:SC 1:1 E, and SBP:SC 1:1 M conjugates at $\mathrm{pH} 4.5$ and $\mathrm{pH} 7$ were transferred to a $100 \mathrm{~mL}$ vial and sealed with a plastic cap. The vial was incubated in a water bath at $80^{\circ} \mathrm{C}$ for $10 \mathrm{~min}$. The samples were stored at $25^{\circ} \mathrm{C}$.

\subsection{Statistical Analysis}

All measured results are reported as the mean $(n=3) \pm 1$ standard deviation of triplicate freshly independent-prepared samples. The data were statistically analysed for significant difference $(p<0.05)$ applying the student's $t$-test by using Microsoft Excel 2010 (Microsoft, Seattle, WA, USA).

\section{Results and Discussion}

\subsection{Physico-Chemical Properties of the SBP-SC Conjugates}

\subsubsection{Visual Appearance}

Figure 1 shows test tubes with the three types of SBP-SC conjugates prepared in this study at $\mathrm{pH} 4.5, \mathrm{pH} 7$ before and after heat treatment $80^{\circ} \mathrm{C}$ for $10 \mathrm{~min}$. At $\mathrm{pH} 4.5$ and before heat treatment, test tubes labelled " 1 ", all conjugates had sedimented and the supernatant phases were clear except for the $\mathrm{P}$ conjugate, which had a milky white supernatant phase. Precipitate colour was white for $\mathrm{P}$ and $\mathrm{M}$ conjugates while the $\mathrm{E}$ conjugate was brown (appearing as grey in the $\mathrm{b} / \mathrm{w}$ image). It can, therefore, be postulated that the microstructure of these conjugates differed with conjugate type. The appearance of the test tubes, labelled " 3 " in Figure 1, reveals that all three types of conjugates became transparent following adjustment of their $\mathrm{pH}$ to $\mathrm{pH}$ 7. This indicates the absence of large aggregates.

However, there were no obvious differences in visual appearance between unheated and heated SBP-SC conjugates, as revealed by comparing test tubes 1 with test tubes 2 , and test tubes 3 with test tubes 4 . This observation confirms previous report that polysaccharides may protect proteins from aggregation during heat treatment [21].

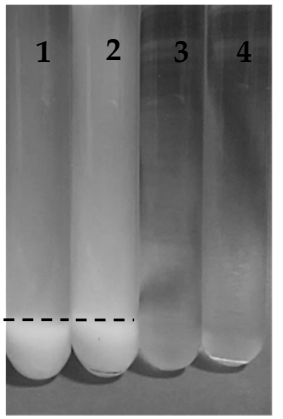

(a)

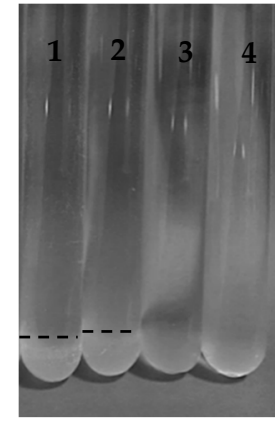

(b)

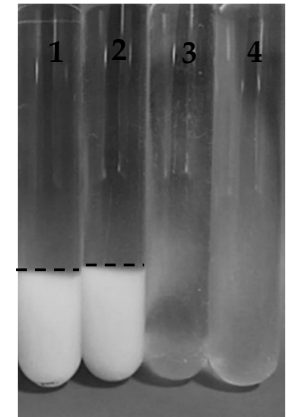

(c)

Figure 1. Images of (a) SBP-SC P conjugates, (b) SBP-SC E conjugates, and (c) SBP-SC M conjugates dispersions (1) at $\mathrm{pH} 4.5$; (2) at $\mathrm{pH} 4.5$ heated at $80{ }^{\circ} \mathrm{C}$ for $10 \mathrm{~min}$; (3) at $\mathrm{pH} 7$; and (4) at $\mathrm{pH} 7$ heated at $80^{\circ} \mathrm{C}$ for $10 \mathrm{~min}$, respectively. The dotted line is the phase boundary of the sediment. 


\subsubsection{Conjugate Size and Zeta Potential}

Prior to Heat Treatment

In order to analyse the particle size of the SBP-SC conjugates, the z-average radius was determined by dynamic light scattering (DLS). The results are shown in Figure 2. At $\mathrm{pH} 4.5, \mathrm{P}$ conjugates were characterised by a larger particle size than seen in E conjugates ( $p$-value $<0.05)$. The particle size of the $\mathrm{M}$ conjugates at $\mathrm{pH} 4.5$ is not reported, as the dispersion was fully precipitated once preparation was complete, and thus the particle size was out of the measurement range of the equipment, i.e., larger than $2,000 \mathrm{~nm}$. When the $\mathrm{pH}$ conditions of the dispersions were adjusted from $\mathrm{pH} 4.5$ to $\mathrm{pH} 7$, the particle size of the P conjugate decreased to from $(259 \pm 23) \mathrm{nm}$ to $(183 \pm 31) \mathrm{nm}$, which was similar to that observed for the E conjugate $(188 \pm 19) \mathrm{nm}$ at $\mathrm{pH} 7$ ( $p$-value $>0.05)$. The particle size of the E conjugate did not change significantly on $\mathrm{pH}$ adjustment ( $p$-value $>0.05$ ). The particle size of the $\mathrm{M}$ conjugate $(213 \pm 19) \mathrm{nm}$ was larger than the particle sizes for the $\mathrm{P}$ and $\mathrm{E}$ conjugates at $\mathrm{pH} 7$ ( $p$-value $<0.05)$. When the $\mathrm{P}$ and $\mathrm{M}$ conjugates were at $\mathrm{pH} 4.5$, the white precipitates were a result of SC self-assembly under acidic conditions. Consequently, both conjugates possessed a large particle size at $\mathrm{pH} 4.5$. Comparatively, the E conjugate displayed a brown precipitate. This result may indicate a lower level of SC aggregation in the E conjugate, leading to a precipitate colour resembling the colour of the $\mathrm{SBP}$ solution (brown) and small particle size at $\mathrm{pH}$ 4.5. When the $\mathrm{P}$ and $\mathrm{M}$ conjugates were adjusted from $\mathrm{pH} 4.5$ to $\mathrm{pH} 7$, their particle size decreased. This result corresponds to the visual observation that $\mathrm{P}$ and $\mathrm{M}$ conjugates showed white precipitates at $\mathrm{pH} 4.5$ that become transparent as the $\mathrm{pH}$ was raised to $\mathrm{pH} 7$. The decreased particle size for both conjugates implies that the SC conjugates were de-agglomerated at $\mathrm{pH} 7$. There was no significant change for the particle size of the E conjugate as the $\mathrm{pH}$ was adjusted from $\mathrm{pH} 4.5$ to $\mathrm{pH} 7$, although the precipitates of the dispersion were changed slightly under this adjustment. This indicates that less aggregation was observed in the E conjugate dispersion at $\mathrm{pH} 4.5$, suggesting that the E conjugate was more acid-tolerant.

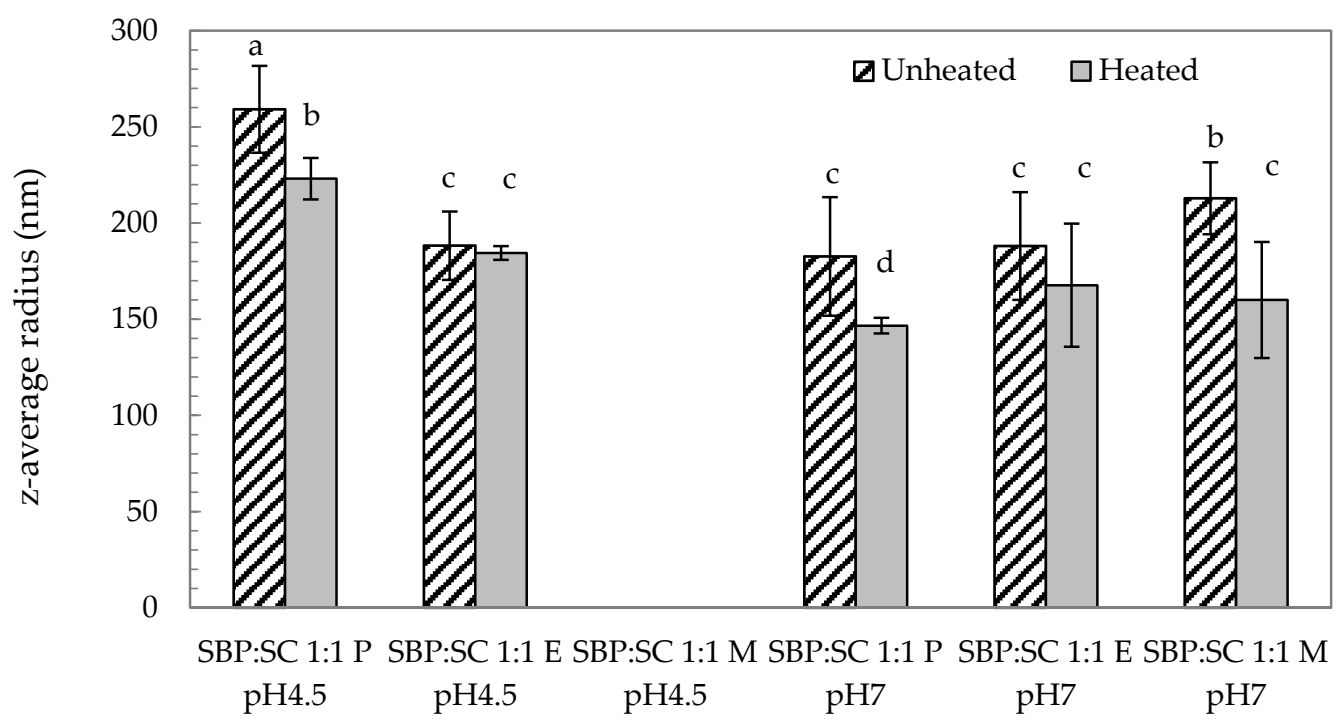

Figure 2. Particle size (z-average radius) of unheated (patterned bars) and heated (filled bars; $80{ }^{\circ} \mathrm{C}$ for $10 \mathrm{~min}$ ) of SBP-SC conjugates at $\mathrm{pH} 4.5$ and $\mathrm{pH} \mathrm{7}$, analysed at $20^{\circ} \mathrm{C}$. The letters (a-d) represent significant differences among samples $(p$-value $<0.05)$. No data are shown for SBP:SC 1:1 M, unheated and heated, as the values were outside the measurement range (upper limit of $2000 \mathrm{~nm}$ ).

To measure the charge of the SBP-SC conjugate dispersions, the $\zeta$-potential was determined. The results are shown in Figure 3. Among these, the $\zeta$-potential of the P conjugate at $\mathrm{pH} 4.5$ was the most negative of the three conjugate types while the $\mathrm{E}$ conjugate had the same negative $\zeta$-potential as the M conjugate. Although the $\zeta$-potential of SC at pH 4.5 was not tested in this study, it was reported 
in a previous study that SC polymers possess a small positive charge at $\mathrm{pH} 4.5$ [10], which is just below the isoelectric point ( $\mathrm{pH} \sim 4.6$ ) of SC. Consequently, the negative $\zeta$-potential of the SBP-SC conjugates is likely to be the result of the presence of SBP polymers creating a net negative charge. In addition, both, the $\mathrm{E}$ and $\mathrm{M}$ conjugates possessed lower net charges at $\mathrm{pH} 4.5$ than the $\mathrm{P}$ conjugate, which implies that there were buried negative carboxyl groups within the $\mathrm{E}$ and $\mathrm{M}$ conjugates. Although the preparation of the E conjugates was based on the P conjugates, the addition of laccase would have altered the structure of the conjugates. These buried carboxyl groups in the E conjugate may thus be the result of covalent cross-links between the ferulic acid present in the SBP and certain amino acids, such as tryptophan, cysteine and tyrosine in the SC, during laccase catalysis [21]. The buried negative groups in the $\mathrm{M}$ conjugates were the result of the reducing end of the carbohydrate cross-linking with the amino acids present in the protein during the Maillard reaction. Although the $\zeta$-potentials of the $\mathrm{E}$ and $\mathrm{M}$ conjugates were similar and especially negative (at both $\mathrm{pH}$ values), the visual observations and the particle size data revealed precipitation and aggregation of the $\mathrm{M}$ conjugates at $\mathrm{pH} 4.5$. This suggests that the protein moieties of the Maillard conjugates interacted hydrophobically, as charge repulsion between these moieties would have been negligible, due to the $\mathrm{pH}$ being close to the IEP of the protein. It appears that the net conjugate charge was dominated by the properties of the SPB. When the $\mathrm{pH}$ of the SBP-SC conjugates was adjusted to $\mathrm{pH} 7$, a more negative $\zeta$-potential was observed for all three SBP-SC conjugates, which may be the result of the negative charge of SC at $\mathrm{pH} 7$. In addition, there were no significant differences in $\zeta$-potential between the $\mathrm{P}, \mathrm{E}$ and $\mathrm{M}$ conjugates at $\mathrm{pH} 7$ ( $p$-value $>0.05$ ).

\section{Post Heat Treatment}

To assess thermal stability, an important factor for the application of food ingredients in general, and particularly for those with structure functionality, the conjugate dispersions were heat treated at $80^{\circ} \mathrm{C}$ for $10 \mathrm{~min}$. Firstly, particle size data (Figure 2) revealed that the particle size of the P conjugate decreased as a result of the heat treatment at both $\mathrm{pH} 4.5$ and $\mathrm{pH} 7$ ( $p$-value $<0.05$ ). In addition, there was no significant change ( $p$-value $>0.05)$ in the $\zeta$-potential of the $\mathrm{P}$ conjugate after heat treatment at $\mathrm{pH} 4.5$, whereas it became more negative at $\mathrm{pH} 7$. A decrease particle size of the P conjugate at $\mathrm{pH} 4.5$ after heat treatment suggests that a structural rearrangement took place during heat treatment. Heat induced structural rearrangement of protein-polysaccharide conjugates from a random structure, to a particle characterised by a protein core with a surrounding polysaccharide shell, has previously been discussed [34,40-44]. The protein core formation could be related to the denaturation of casein at $\mathrm{pH} 4.5$ at $80^{\circ} \mathrm{C}[45,46]$. Smaller particle size and higher $\zeta$-potential may suggest that a structural change of the $\mathrm{P}$ conjugate at $\mathrm{pH} 7$ during heat treatment. Due to the strong electrostatic repulsion between SBP and SC biopolymers under neutral conditions, heat treatment can lead to the separation of a fraction of the protein from the conjugates increasing the net negative charge of the system [44]. Secondly, heating had a lesser effect on the E conjugate, as indicated by the particle size remaining constant, but the $\zeta$-potential decreased slightly at $\mathrm{pH} 4.5$. This change can be attributed to the heat-induced weakening of the unfolded structures of SBP-SBP conjugates in E conjugates, because the covalent bond weakened after heat treatment, leading to the exposure of some negatively charged groups. The fact that the $\zeta$-potential of the $\mathrm{E}$ conjugates held at $\mathrm{pH} 7$ was not affected by heating suggests that separation of the E conjugate was either completely absent, due to the molecularly cross-linked nature of this conjugate type, or too insignificant to affect the $\zeta$-potential. Finally, the consequence of heat treating the $\mathrm{M}$ conjugate type held at $\mathrm{pH} 4.5$ could only be assessed by the $\zeta$-potential, as the particles were still too large for the selected particle sizing method (DLS). A less negative $\zeta$-potential was recorded for the $\mathrm{M}$ conjugate after heat treatment at $\mathrm{pH} 4.5$, increasing from $(-29.18 \pm 0.52) \mathrm{mV}$ to $(-28.26 \pm 0.24) \mathrm{mV}$, shown in Figure 3. This result was probably due to the structural rearrangement of SBP-SC conjugates contributing to reducing the negative charge. The results at $\mathrm{pH} 7$ revealed that the particle size of the M conjugate decreased from $(213 \pm 19) \mathrm{nm}$ to $(160 \pm 14) \mathrm{nm}$ after heating ( $p$-value $<0.05)$, shown in Figure 2 . In addition, no significant change in $\zeta$-potential at pH 7 after 
thermal treatment ( $p$-value $>0.05$ ) was found, see Figure 3. The smaller particle size may suggest that the $\mathrm{M}$ conjugates were slightly less aggregated after heat treatment.

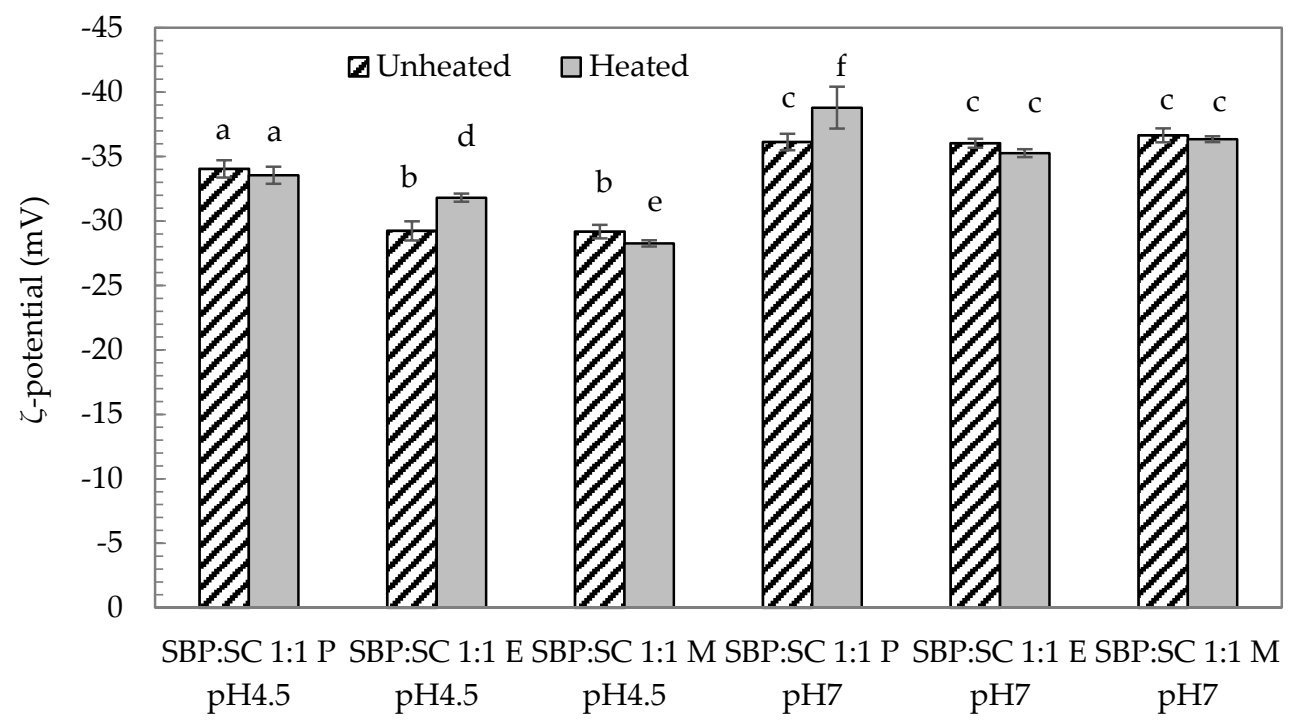

Figure 3. $\zeta$-potential of unheated (upward) and heated (filled) at $80^{\circ} \mathrm{C}$ for $10 \mathrm{~min}$ of SBP-SC conjugates at $\mathrm{pH} 4.5$ and $\mathrm{pH} 7$ at $20^{\circ} \mathrm{C}$. The different letters (a-f) represent significant differences among samples ( $p$-value $<0.05)$.

\subsubsection{Steady Shear Viscosity}

The conjugate dispersions were assessed for steady shear viscosity behaviour and the results are shown in Figure 4. At pH 4.5 and prior to heating, but in fact, after heating as discussed later, all three types of conjugate dispersions were shear-thinning. This shear-thinning behaviour was more pronounced for the $\mathrm{M}$ conjugate dispersion, compared to the $\mathrm{P}$ conjugate dispersion, which was more shear thinning than the E conjugate dispersion, see Figure 4a. The more pronounced shear-thinning of the $\mathrm{M}$ conjugate dispersion would have been the consequence of the aggregated state of the conjugate [47]. Analogously, as the P conjugate demonstrated stronger aggregation than the E conjugates, their degree of shear-thinning was comparatively higher. One of the most important parameters affecting the rheology of dispersed systems is particle volume fraction, and shear-thinning behaviours are the result of intermediate volume fractions $(0.1<\varphi<0.5)$ [48]. It has been reported that higher particle volume fractions in this intermediate volume range result in higher shear viscosity because of the formation of chains and networks of interacting particles. In this case, the magnitude of the shear viscosity is related to the particle size and the coefficient of friction between particles [49]. In this study, the larger aggregated particles of the $\mathrm{M}$ conjugates render this conjugate dispersion the highest viscous of the three conjugate dispersions. When the $\mathrm{pH}$ condition was adjusted to $\mathrm{pH} 7$, see Figure $4 b$, shear-thinning was less pronounced for $P$ and $M$ conjugates. This result further evidences the aggregation of $\mathrm{P}$ and $\mathrm{M}$ conjugates at $\mathrm{pH} 4.5$ but not at $\mathrm{pH}$ 7. Comparatively, the $\mathrm{E}$ conjugates were less influenced by the altered $\mathrm{pH}$ condition, with no change in flow behaviour as the conditions changed from $\mathrm{pH} 4.5$ to $\mathrm{pH} 7$. 


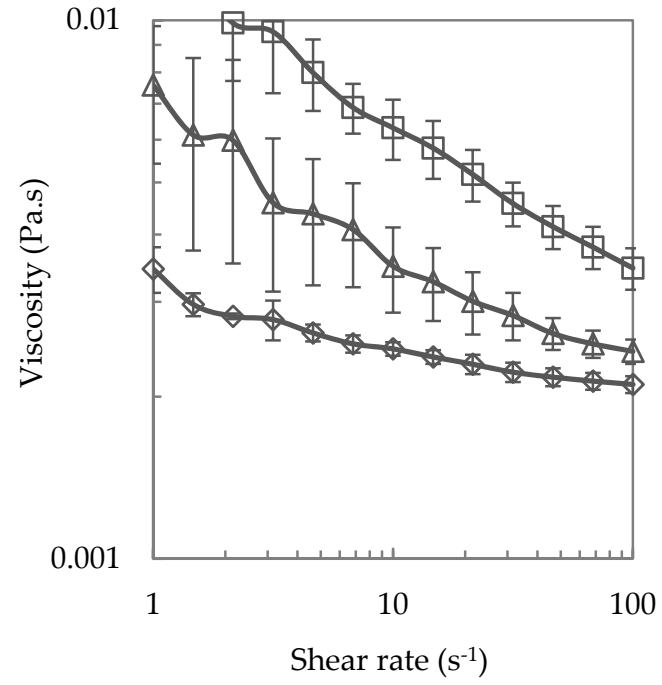

(a)

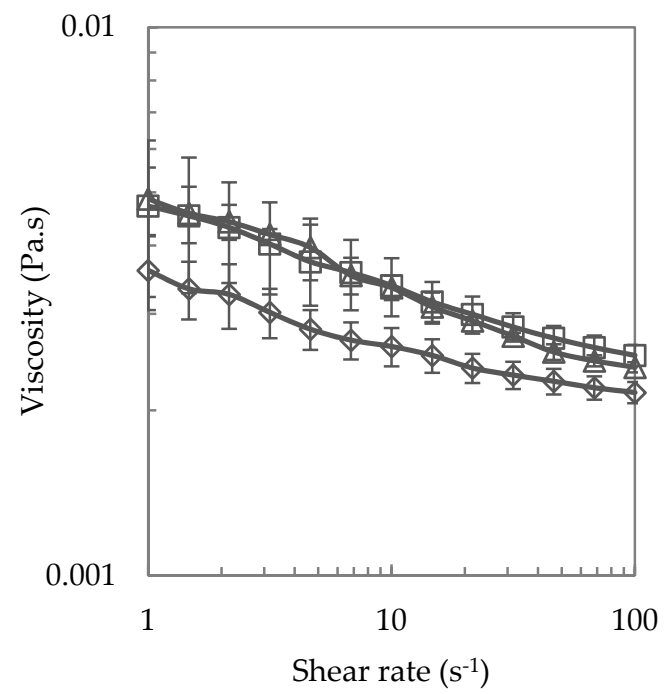

(c)

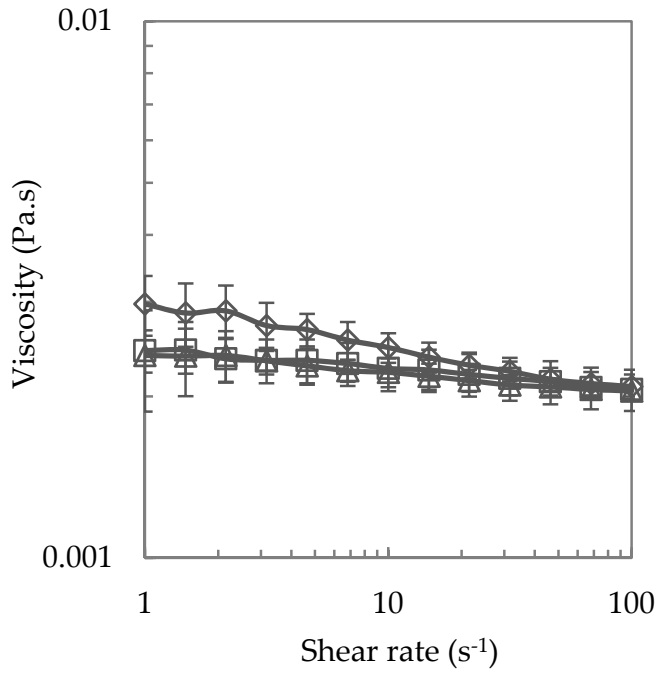

(b)

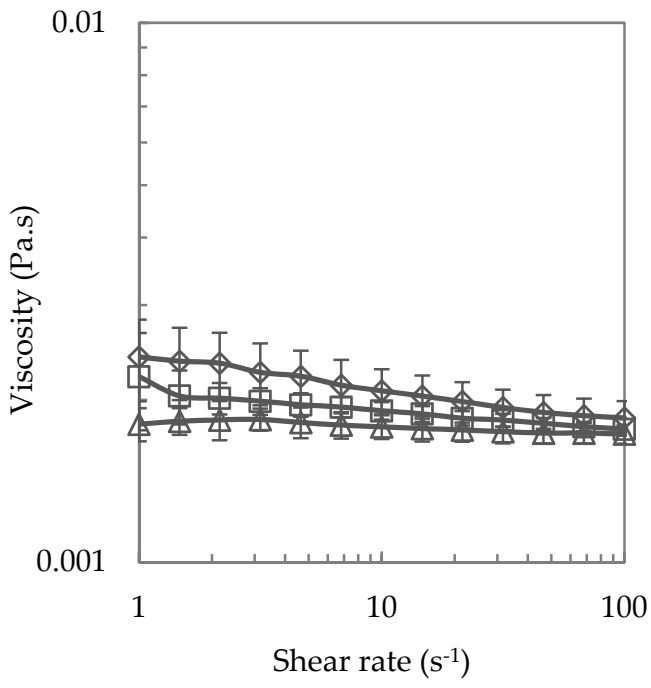

(d)

Figure 4. Steady shear viscosity (a) at $\mathrm{pH} 4.5$; (b) at $\mathrm{pH} 7$; (c) heated at $80{ }^{\circ} \mathrm{C}$ and $\mathrm{pH} 4.5$ for $10 \mathrm{~min}$; (d) heated at $80^{\circ} \mathrm{C}$ and $\mathrm{pH} 7$ for $10 \mathrm{~min}$ of SBP:SC 1:1 P (triangle), SBP:SC 1:1 E (diamond), and SBP:SC 1:1 $\mathrm{M}$ (square) conjugates measured at $20{ }^{\circ} \mathrm{C}$. The values are means, and the error bars correspond to $\mathrm{a} \pm 1$ standard deviation of the triplicate measurements taken from freshly prepared samples.

To understand the viscosity behaviours of the SBP-SC conjugates after thermal treatment, rotational rheological measurement was performed on the heated conjugate dispersions. In Figure 4c, it is revealed that there was a decrease in viscosity for both $\mathrm{P}$ and $\mathrm{M}$ conjugates, as compared with unheated SBP-SC conjugates at $\mathrm{pH}$ 4.5. The decreased particle size may contribute to the decrease of the shear viscosity for the $\mathrm{P}$ conjugate dispersion after heat treatment as it means a lower particle volume fraction. The decreased viscosity of the $\mathrm{M}$ conjugate dispersion after heat treatment suggests that the particle size of the conjugates was lower after heat treatment (but still $>2000 \mathrm{~nm}$, as explained earlier). As previously interpreted from the $\zeta$-potential results, following heat treatment at $\mathrm{pH} 4.5$, the $\mathrm{M}$ conjugates most likely had a core of denatured SC, surrounded by a shell of SBP. Comparatively, a slight decrease and no obvious change in viscosity were observed for the $\mathrm{P}$ and $\mathrm{E}$ conjugate dispersions, as a result of heating at $\mathrm{pH} 4.5$, comparison data is shown in Figure $4 \mathrm{a}$,c. This phenomenon may be a result of the 
decreased particle size of the $\mathrm{P}$ conjugates due to heating and the heat had less effect on the size of the E conjugates, see Figure 2, heating at $\mathrm{pH} 7$ on the other hand did not change viscosity for any of the three dispersions, comparison data is shown in Figure $4 \mathrm{~b}$,d. On analysing the particle size and $\zeta$-potential, there were no significant changes for the $\mathrm{E}$ conjugate at $\mathrm{pH} 7$ after heat treatment, and thus no shear viscosity changes. This result further shows the reduced effect of heating on the E conjugate. However, decreased particle sizes were observed for both $\mathrm{P}$ and $\mathrm{M}$ conjugates, which may contribute to less viscosity in both dispersions after heat treatment. In the shear viscosity results, such phenomena were not observed, perhaps as the particle size decrease was too little.

\subsection{Microstructure Model}

The physico-chemical data, acquired on the three types of SBP-SC conjugates, were interpreted in terms microstructure models pre- and post-heating, see Figure 5a,b respectively. The references in the figure captions refer to previously published models for protein-polysaccharide conjugate structures, but non SBP-SC.

A possible structure of the SBP-SC conjugates at $\mathrm{pH} 4.5$ and $\mathrm{pH} 7$ is shown in Figure 5a. P and $\mathrm{E}$ conjugates were hypothesised to possess similar structures at $\mathrm{pH} 4.5$ because of the folded structure of the SC biopolymer at this for casein proteins unfavourable $\mathrm{pH}$. However, there were slight differences because of the additional laccase catalysed cross-linking between SBP and SBP within E conjugate, leading to a higher branched structure of SBP in the E conjugate [26]. In contrast, there is a high degree of covalent bonding between the amine groups of the SC and the aldehydes groups of the SBP during the Maillard reaction, leading to unfolded SC and SBP structures within M conjugates. Under acid conditions, the unfolded SC in the M conjugates is aggregated, resulting in more pronounced aggregation and thus precipitation. At $\mathrm{pH} 7$, similar aggregation properties were observed for $\mathrm{P}, \mathrm{E}$, and $\mathrm{M}$ conjugates, favouring the coil confirmation of SBP and SC, and suggesting that a similar structure pertains among all three SBP-SC conjugates. Moreover, the large particle size for M conjugate may be a result of more than one SBP cross-linked with SC during Maillard reaction [50]. Comparatively, only one the SBP molecule, cross-linked with one SC molecule in both P and E conjugates [51]. A possible structural rearrangement of $\mathrm{P}, \mathrm{E}$ and $\mathrm{M}$ conjugates after heat treatment at $\mathrm{pH} 4.5$ is shown in Figure 5b. Previous studies suggested that the structural rearrangement of SBP-SC conjugates, during heat treatment, may reinforce the stability of SBP-SC conjugates because of the structure of a protein core with a surrounding polysaccharide shell [44].

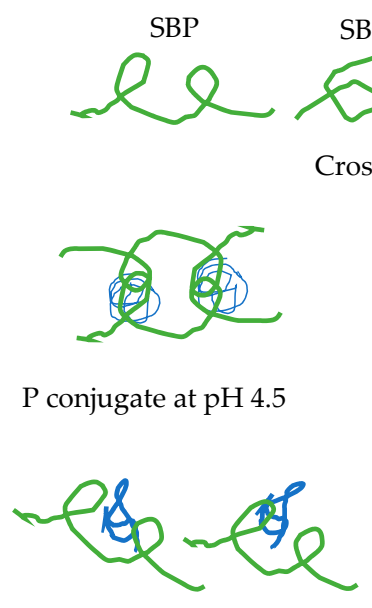

$\mathrm{P}$ conjugate at $\mathrm{pH} 7$
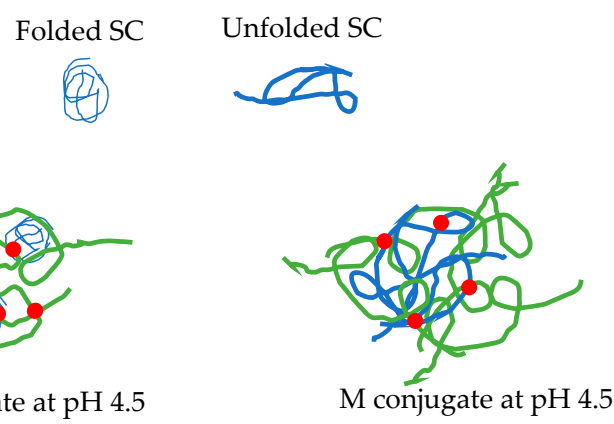

E conjugate at $\mathrm{pH} 4.5$

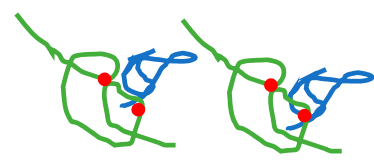

E conjugate at $\mathrm{pH} 7$

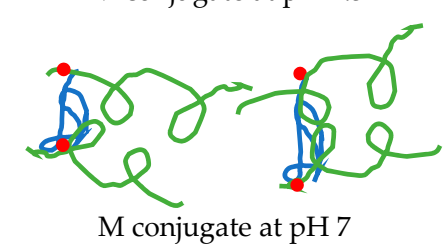

$\mathrm{M}$ conjugate at $\mathrm{pH} 7$

(a)

Figure 5. Cont. 


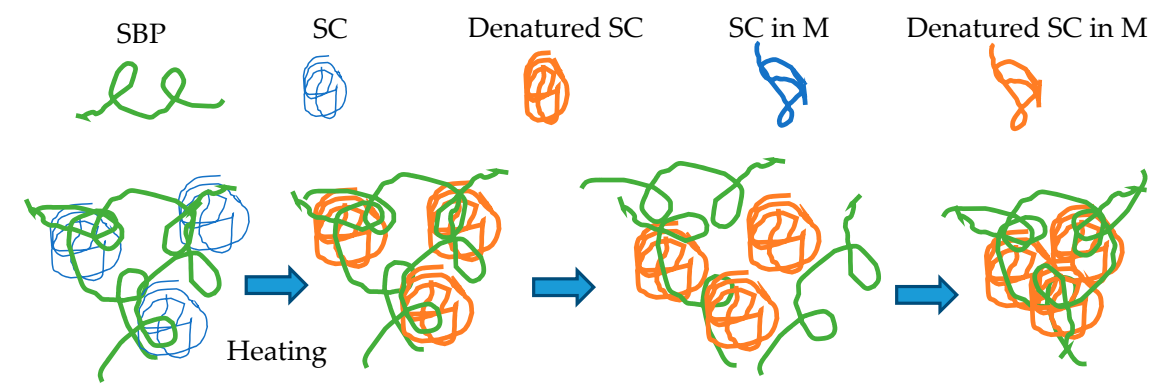

P conjugate

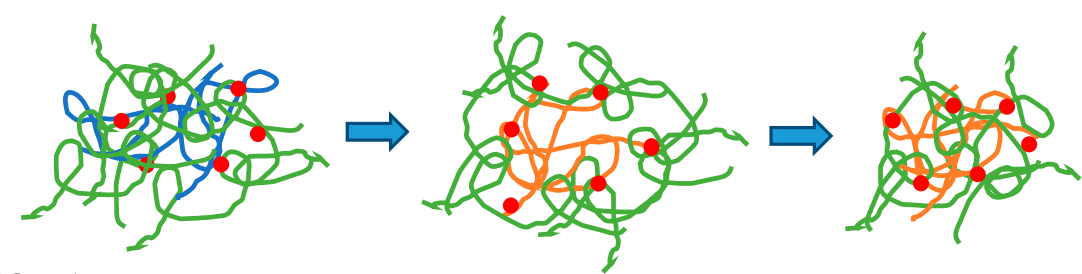

M conjugate

(b)

Figure 5. Schematic of (a) SBP-SC conjugate via complexation [2], laccase catalysis [30], and Maillard reaction [6,31] at $\mathrm{pH} 4.5$ and $\mathrm{pH} 7$; and (b) the structure of $\mathrm{P}$ and $\mathrm{M}$ conjugates at $\mathrm{pH} 4.5$ heated at $80{ }^{\circ} \mathrm{C}$ for $10 \mathrm{~min}$ [38].

\section{Conclusions}

In this study, the aggregation properties of electrostatically-stabilised, laccase-catalysed and Maillard cross-linked SBP-SC conjugates were studied at different environmental stresses. The $\mathrm{pH}$ and thermal treatment affected the aggregation properties of all three types of conjugates. The $\mathrm{E}$ conjugate was most acid tolerant, followed by the $\mathrm{P}$ conjugate, while the $\mathrm{M}$ conjugate was the least acid-tolerant. This conclusion is based on the lowest precipitate volume, smallest mean particle size and least degree of shear-thinning behaviour of this conjugate type at $\mathrm{pH} 4.5$. When the condition was adjusted to $\mathrm{pH} 7$, all three dispersions revealed similar aggregation properties. Based on the aggregate property data, it could be concluded that the P conjugate was the structure of folded SC cross-linked with SBP, E conjugates was the structure of folded SC, cross-linked with more compact, higher branches SBP, and $\mathrm{M}$ conjugates was the structure of unfolded SC cross-linked with one or two SBPs. Heat treatment led to a structuring re-arrangement with the degree of re-arrangement depending on conjugate type. At $\mathrm{pH} 4.5$ the microstructure model proposes a protein core with a surrounding polysaccharide shell. During heating at $\mathrm{pH} 7, \mathrm{SC}$ separated from P conjugates, whereas E and M conjugates were hardly affected by heating, probably as SC and SBP were covalently cross-linked. So, it can be concluded that the covalently cross-linked conjugates were more heat-resistance than the electrostatically cross-linked conjugate and would, therefore, be a preferred choice for acidic emulsion-based food and drink formulations requiring pasteurisation.

Supplementary Materials: The following are available online at http://www.mdpi.com/2304-8158/8/6/192/s1, Figure S1. (a) Standard absorbance of ferulic acid concentration in sugar beet pectin at $325 \mathrm{~nm}$ wavelength and $25^{\circ} \mathrm{C}$; (b) Influence of different enzyme concentrations on time-dependence of absorbance at $325 \mathrm{~nm}$ of $0.4 \mathrm{w} / \mathrm{w} \%$ sugar beet pectin dispersions at $\mathrm{pH} 5$ (citrate buffer $50 \mathrm{mM}$ ) at $25^{\circ} \mathrm{C}$. Table S1: Effect of thermal treatment at $80^{\circ} \mathrm{C}$ for $10 \mathrm{~min}$ on particle size and $\zeta$-potential of SBP-SC conjugates at $\mathrm{pH} 4.5$ and $\mathrm{pH} 7$ at $20^{\circ} \mathrm{C}$. In this section, the ferulic acid concentration and the activity of laccase on sugar beet pectin have been analysed, as shown in Figure S1a. $0.1 \% w / w$ SBP dispersion was measured at $325 \mathrm{~nm}$ and $25^{\circ} \mathrm{C}$, and the absorbance of $0.1 \% w / w$ SBP was 0.866 from $1.33 \mathrm{mg} / 100 \mathrm{~g}$ ferulic acid. Thus, the sugar beet pectin used in this research contained $1.33 \%$ ferulic acid. In Figure S1b, 5 AU and 10 AU laccase possessed lower absorbances than $1 \mathrm{AU}$ and 20 AU during laccase catalysis, suggesting that 5 AU appeared to be sufficient to fully cross-link ferulic acid with each other in sugar beet pectin. Therefore, 5 AU laccase was used to cross-link SBP-SC conjugate in this study. 
Author Contributions: J.Z. conceived the research project and designed experiments with B.W. J.Z. carried out all experiments. J.Z. drafted the manuscript; B.W. supervised its preparation; all authors were involved in revising it. All authors have approved and are accountable for the final version of the manuscript submitted.

Funding: This research received no external funding.

Acknowledgments: Tim Foster and Stephen Harding (University of Nottingham, UK) are acknowledged for discussion, and Herbstreith and Fox KG (Neuenbürg, Germany) for suppling the sugar beet pectin.

Conflicts of Interest: The authors declare no conflict of interest.

\section{References}

1. Schmitt, C.; Sanchez, C.; Desobry-Banon, S.; Hardy, J. Structure and technofunctional properties of protein-polysaccharide complexes: A review. Crit. Rev. Food Sci. Nutr. 1998, 38, 689-753. [CrossRef] [PubMed]

2. Tolstoguzov, V.B. Functional properties of food proteins and role of protein-polysaccharide interaction. Food Hydrocoll. 1991, 4, 429-468. [CrossRef]

3. Madene, A.; Jacquot, M.; Scher, J.; Desobry, S. Flavour encapsulation and controlled release-A review. Int. J. Food Sci. Technol. 2006, 41, 1-21. [CrossRef]

4. Champagne, C.P.; Fustier, P. Microencapsulation for the improved delivery of bioactive compounds into foods. Curr. Opin. Biotechnol. 2007, 18, 184-190. [CrossRef] [PubMed]

5. Wen-Sherng, C.; Henry George, A.; Gaud Susan, M.; Miller Mark, S.; Kaiser John, M.; Balmadeca Estela, A.; Morgan Ronnie, G.; Baer Cynthia, C.; Borwankar Rajendra, P.; Hellgeth Lorraine, C.; et al. Microfragmented Ionic Polysaccharide/Protein Complex Dispersions. U.S. Patent Application No. US07/548,950, 28 April 1989.

6. Zolper John, T. Fat Substitutes Based on Carrageenan Gels, Processes for Producing the Same and Food Products Containing the Fat Substitutes. U.S. Patent Application No. US08/139,855, 22 November 1993.

7. Soucie William, G.; Chen, W.-S.; Witte Vernon, C.; Henry George, A.; Drehkoff, W.D. Shelf Stable Acid Food Dressings Containing Fibrous Protein Complexes. U.S. Patent Application No. US07/024,507, 1 July 1985.

8. Bishay Ihab, E.; Clark Deane, R. Carbohydrate/Protein Cream Substitutes. U.S. Patent Application No. US08/438,798, 11 May 1995.

9. Surh, J.; Decker, E.A.; McClements, D.J. Influence of $\mathrm{pH}$ and pectin type on properties and stability of sodium-caseinate stabilized oil-in-water emulsions. Food Hydrocoll. 2006, 20, 607-618. [CrossRef]

10. Li, X.Y.; Fang, Y.P.; Phillips, G.O.; Al-Assaf, S. Improved Sugar Beet Pectin-Stabilized Emulsions through Complexation with Sodium Caseinate. J. Agric. Food Chem. 2013, 61, 1388-1396. [CrossRef]

11. Dickinson, E. Hydrocolloids as emulsifiers and emulsion stabilizers. Food Hydrocoll. 2009, 23, $1473-1482$. [CrossRef]

12. Semo, E.; Kesselman, E.; Danino, D.; Livney, Y.D. Casein micelle as a natural nano-capsular vehicle for nutraceuticals. Food Hydrocoll. 2007, 21, 936-942. [CrossRef]

13. Dickinson, E. Proteins at interfaces and in emulsions-Stability, rheology and interactions. J. Chem. Soc. Faraday Trans. 1998, 94, 1657-1669. [CrossRef]

14. Dickinson, E. Milk protein interfacial layers and the relationship to emulsion stability and rheology. Colloids Surf. B Biointerfaces 2001, 20, 197-210. [CrossRef]

15. Livney, Y.D. Milk proteins as vehicles for bioactives. Curr. Opin. Colloid Interface Sci. 2010, 15, 73-83. [CrossRef]

16. Leroux, J.; Langendorff, V.; Schick, G.; Vaishnav, V.; Mazoyer, J. Emulsion stabilizing properties of pectin. Food Hydrocoll. 2003, 17, 455-462. [CrossRef]

17. Funami, T.; Zhang, G.Y.; Hiroe, M.; Noda, S.; Nakauma, M.; Asai, I.; Cowman, M.K.; Al-Assaf, S.; Phillips, G.O. Effects of the proteinaceous moiety on the emulsifying properties of sugar beet pectin. Food Hydrocoll. 2007, 21, 1319-1329. [CrossRef]

18. Siew, C.K.; Williams, P.A. Characterization of the surface-active components of sugar beet pectin and the hydrodynamic thickness of the adsorbed pectin layer. J. Agric. Food Chem. 2008, 56, 8111-8120. [CrossRef] [PubMed]

19. Siew, C.K.; Williams, P.A. Role of protein and ferulic acid in the emulsification properties of sugar beet pectin. J. Agric. Food Chem. 2008, 56, 4164-4171. [CrossRef] [PubMed] 
20. Evans, M.; Ratcliffe, I.; Williams, P.A. Emulsion stabilisation using polysaccharide-protein complexes. Curr. Opin. Colloid Interface Sci. 2013, 18, 272-282. [CrossRef]

21. Jones, O.G.; McClements, D.J. Functional Biopolymer Particles: Design, Fabrication, and Applications. Compr. Rev. Food Sci. Food Saf. 2010, 9, 374-397. [CrossRef]

22. Ridley, B.L.; O'Neill, M.A.; Mohnen, D.A. Pectins: Structure, biosynthesis, and oligogalacturonide-related signaling. Phytochemistry 2001, 57, 929-967. [CrossRef]

23. Mattinen, M.L.; Kruus, K.; Buchert, J.; Nielsen, J.H.; Andersen, H.J.; Steffensen, C.L. Laccase-catalyzed polymerization of tyrosine-containing peptides. FEBS J. 2005, 272, 3640-3650. [CrossRef] [PubMed]

24. Zeeb, B.; Fischer, L.; Weiss, J. Stabilization of food dispersions by enzymes. Food Funct. 2014, 5, $198-213$. [CrossRef] [PubMed]

25. Mattinen, M.L.; Hellman, M.; Permi, P.; Autio, K.; Kalkkinen, N.; Buchert, J. Effect of protein structure on laccase-catalyzed protein oligomerization. J. Agric. Food Chem. 2006, 54, 8883-8890. [CrossRef] [PubMed]

26. Jung, J.Y.; Wicker, L. Laccase mediated conjugation of sugar beet pectin and the effect on emulsion stability. Food Hydrocoll. 2012, 28, 168-173. [CrossRef]

27. Zaidel, D.N.A.; Chronakis, I.S.; Meyer, A.S. Stabilization of oil-in-water emulsions by enzyme catalyzed oxidative gelation of sugar beet pectin. Food Hydrocoll. 2013, 30, 19-25. [CrossRef]

28. Chen, B.C.; Li, H.J.; Ding, Y.P.; Suo, H.Y. Formation and microstructural characterization of whey protein isolate/beet pectin coacervations by laccase catalyzed cross-linking. LWT Food Sci. Technol. 2012, 47, 31-38. [CrossRef]

29. Gazme, B.; Madadlou, A. Fabrication of whey protein-pectin conjugate particles through laccase-induced gelation of microemulsified nanodroplets. Food Hydrocoll. 2014, 40, 189-195. [CrossRef]

30. Zeeb, B.; Gibis, M.; Fischer, L.; Weiss, J. Crosslinking of interfacial layers in multilayered oil-in-water emulsions using laccase: Characterization and pH-stability. Food Hydrocoll. 2012, 27, 126-136. [CrossRef]

31. Zeeb, B.; Lopez-Pena, C.L.; Weiss, J.; McClements, D.J. Controlling lipid digestion using enzyme-induced crosslinking of biopolymer interfacial layers in multilayer emulsions. Food Hydrocoll. 2015, 46, 125-133. [CrossRef]

32. Jung, J.; Wicker, L. beta-Lactoglobulin conformation and mixed sugar beet pectin gel matrix is changed by laccase. LWT Food Sci. Technol. 2014, 55, 9-15. [CrossRef]

33. Littoz, F.; McClements, D.J. Bio-mimetic approach to improving emulsion stability: Cross-linking adsorbed beet pectin layers using laccase. Food Hydrocoll. 2008, 22, 1203-1211. [CrossRef]

34. Jones, O.G.; Decker, E.A.; McClements, D.J. Comparison of protein-polysaccharide nanoparticle fabrication methods: Impact of biopolymer complexation before or after particle formation. J. Colloid Interface Sci. 2010, 344, 21-29. [CrossRef]

35. Juvonen, H.; Smolander, M.; Boer, H.; Pere, J.; Buchert, J.; Peltonen, J. Film Formation and Surface Properties of Enzymatically Crosslinked Casein Films. J. Appl. Polym. Sci. 2011, 119, 2205-2213. [CrossRef]

36. Al-Hakkak, M.; Kavale, S. Improvement of emulsification properties of sodium caseinate by conjugating to pectin through the Maillard reaction. Mail. React. Food Chem. Med Sci. Update Postgenomic Era 2002, 1245, 491-499. [CrossRef]

37. Jaeger, H.; Janositz, A.; Knorr, D. The Maillard reaction and its control during food processing. The potential of emerging technologies. Pathol. Biol. 2010, 58, 207-213. [CrossRef] [PubMed]

38. Tamnak, S.; Mirhosseini, H.; Tan, C.P.; Ghazali, H.M.; Muhammad, K. Physicochemical properties, rheological behavior and morphology of pectin-pea protein isolate mixtures and conjugates in aqueous system and oil in water emulsion. Food Hydrocoll. 2016, 56, 405-416. [CrossRef]

39. Bi, B.W.; Yang, H.; Fang, Y.P.; Nishinari, K.; Phillips, G.O. Characterization and emulsifying properties of beta-lactoglobulin-gum Acacia Seyal conjugates prepared via the Maillard reaction. Food Chem. 2017, 214, 614-621. [CrossRef] [PubMed]

40. Jones, O.; Decker, E.A.; McClements, D.J. Thermal analysis of beta-lactoglobulin complexes with pectins or carrageenan for production of stable biopolymer particles. Food Hydrocoll. 2010, 24, 239-248. [CrossRef]

41. Jones, O.G.; Decker, E.A.; McClements, D.J. Formation of biopolymer particles by thermal treatment of beta-lactoglobulin-pectin complexes. Food Hydrocoll. 2009, 23, 1312-1321. [CrossRef]

42. Jones, O.G.; Lesmes, U.; Dubin, P.; McClements, D.J. Effect of polysaccharide charge on formation and properties of biopolymer nanoparticles created by heat treatment of beta-lactoglobulin-pectin complexes. Food Hydrocoll. 2010, 24, 374-383. [CrossRef] 
43. Jones, O.G.; McClements, D.J. Stability of biopolymer particles formed by heat treatment of beta-lactoglobulin/beet pectin electrostatic complexes. Food Biophys. 2008, 3, 191-197. [CrossRef]

44. Jones, O.G.; McClements, D.J. Recent progress in biopolymer nanoparticle and microparticle formation by heat-treating electrostatic protein-polysaccharide complexes. Adv. Colloid Interface Sci. 2011, 167, 49-62. [CrossRef]

45. Sauer, A.; Moraru, C.I. Heat stability of micellar casein concentrates as affected by temperature and $\mathrm{pH}$. J. Dairy Sci. 2012, 95, 6339-6350. [CrossRef] [PubMed]

46. Yang, M.; Zhang, W.B.; Wen, P.C.; Zhang, Y.; Liang, Q. Heat stability of yak micellar casein as affected by heat treatment temperature and duration. Dairy Sci. Technol. 2014, 94, 469-481. [CrossRef]

47. Li, X.B.; Fang, Y.P.; Al-Assaf, S.; Phillips, G.O.; Nishinari, K.; Zhang, H.B. Rheological study of gum arabic solutions: Interpretation based on molecular self-association. Food Hydrocoll. 2009, 23, 2394-2402. [CrossRef]

48. Dickinson, E. An Introduction to Food Colloids; Oxford University Press: Oxford, UK, 1992.

49. Mueller, S.; Llewellin, E.W.; Mader, H.M. The rheology of suspensions of solid particles. Proc. R. Soc. A Math. Phys. Eng. Sci. 2010, 466, 1201-1228. [CrossRef]

50. De Oliveira, F.C.; Coimbra, J.S.D.; de Oliveira, E.B.; Zuniga, A.D.G.; Rojas, E.E.G. Food Protein-polysaccharide Conjugates Obtained via the Maillard Reaction: A Review. Crit. Rev. Food Sci. Nutr. 2016, 56, 1108-1125. [CrossRef] [PubMed]

51. Liu, F.G.; Ma, C.C.; Gao, Y.X.; McClements, D.J. Food-Grade Covalent Complexes and Their Application as Nutraceutical Delivery Systems: A Review. Compr. Rev. Food Sci. Food Saf. 2017, 16, 76-95. [CrossRef]

(C) 2019 by the authors. Licensee MDPI, Basel, Switzerland. This article is an open access article distributed under the terms and conditions of the Creative Commons Attribution (CC BY) license (http://creativecommons.org/licenses/by/4.0/). 